\title{
Potential Approaches to Improving Biodegradation of Hydrocarbons for Bioremediation of Crude Oil Pollution
}

\author{
Qingren Wang, Shouan Zhang, Yuncong Li, Waldemar Klassen
}

Tropical Research and Education Center, University of Florida, Homestead, FL, USA.

Email: qrwang@ufl.edu

Received September $20^{\text {th }}, 2010$; revised November $3^{\text {rd }}, 2010$; accepted December $29^{\text {th }}, 2010$.

\begin{abstract}
With increasing demands of fossil fuel energy, extensive exploration of natural sources has caused a number of large scale accidental spills of crude oil and resulted in some significantly environmental disasters. The consequence of oil pollution to environment and human health has brought a serious challenge to environmental scientists. Physical and chemical approaches to cleanup oil spills are too expensive and create adverse effects. Bioremediation has shown a great potential and competitive privilege because of environment friendly and cost effective. A number of efficient microbial strains have been identified and isolated, which can effectively degrade various components of petroleum oil. However, the biodegradation efficiency is usually limited by abiotic factors, such as temperature and $\mathrm{pH}$, which are hardly to be controlled in the in situ condition but adequate oxygen supply and nutrient balancing are of importance to impact microbial functions. Therefore, this review especially addresses potential approaches to improving bioremediation of crude oil by supplying solid oxygen and adjusting $C: N$ : $P$ ratio to optimize microbial activities in order to improve the effectiveness and efficacy of bioremediation of crude oil pollutants. In addition, it also elucidates advantages of bioremediation, isolation of selective microbial strains, and evaluation of the biodegradation rates.
\end{abstract}

Keywords: Biodegradation, Bioremediation, Crude Oil, Hydrocarbon, Nutrient Balance, Oxygen

\section{Critical Importance and Advantages of Bioremediation}

Oil contamination with petroleum and petroleum-based hydrocarbons in accidental spills has caused critical concerns in environment, ecological systems, human health, tourism and recreation activities. Such pollution to water and soil has become often in recent decades with the increasing demand of fossil fuel energy requiring offshore drilling due to the global population growth and persistent persuasion for an increase of GDP. Indeed oil spill has resulted in some environmental disasters throughout the world. For example, the Lakeview Gusher spill in California reached up to 1200000 tons of crude oil from May 1910 to September 1911, which was the largest spill in the world history [1]. Since the late of 1970s, there has been a number of large spills [2,3] around the world (Table 1) and the consequence of oil spill pollution can last decades. For instance, the smallest spill among 13 major spills occurred in 1989 by the Exxon Valdez in Prince William Sound of Alaska caused about 100 tons of oil still remained in the beaches of Prince William Sound as of 2001 [4]. The incident of oil spill from BP in the Gulf Coast of Mexico from April to July, 2010, has caused almost 600000 tons of crude oil spilled along the Gulf Coast. The total amount of all major spills was as much as 37 billion barrels of crude oil, which exceeds the total amount of crude oil consumption for the entire world annually (30 billion barrels in 2006) [5]. All these spills have caused tremendous damage to ecological and environmental systems, especially to many plant species, a wide array of animals, human health, which resulted in the alteration of the coast aesthetics for tourism and recreations.

Oil spills can leave a legacy for decades, even centuries into the future. The deaths of marine animals and migratory birds and impacts of their losses on marine ecosystems, and on human health effects by oil spills are difficult to evaluate [6]. Cleanup efforts will require decades of dedicated work, and conversion of a toxic environment to a healthy one will need long time and 
Table 1. Major oil spills in the world by order of quantity [2].

\begin{tabular}{|c|c|c|c|c|}
\hline Date & Location & Spill type & Tons of crude oil & Barrels \\
\hline 5/14/1910-9/10/1911 & U.S. Kern County, California & Lakeview Gusher & 1200000 & 9000000 \\
\hline $4 / 20-7 / 15,2010$ & U.S. Gulf of Mexico & Deepwater horizon & $560000-585000$ & $4100000-4300000$ \\
\hline $1 / 23 / 1991$ & Iraq, Persian Gulf and Kuwait & Gulf War oil spill & $270000-820000$ & $2000000-6000000$ \\
\hline 6/3/1979-3/23/1980 & Mexico, Gulf of Mexico & Ixtoc I & $454000-480000$ & $3329000-3520000$ \\
\hline $7 / 19 / 1979$ & Trinidad and Tobago & Atlantic Empress/Aegean Captain & 287000 & 2105000 \\
\hline $3 / 2 / 1992$ & Uzbekistan & Fergana Valley & 285000 & 2090000 \\
\hline $2 / 4 / 1983$ & Iran, Persian Gulf & Nowruz Field Platform & 260000 & 1907000 \\
\hline $5 / 28 / 1991$ & Angola & ABT Summer offshore & 260000 & 1907000 \\
\hline $8 / 6 / 1983$ & South Africa, Saldanha Bay & Castillo de Bellver & 252000 & 1848000 \\
\hline $3 / 16 / 1978$ & France, Brittany & Amoco Cadiz & 223000 & 1635000 \\
\hline $4 / 11 / 1991$ & Italy, Mediterranean Sea Near Genoa & MT Haven & 144000 & 1056000 \\
\hline $11 / 10 / 1988$ & Canada & Odyssey & 132000 & 968000 \\
\hline $3 / 24 / 1989$ & U.S. Prince William Sound, Alaska & Exxon Valdez oil tanker & $35065-103896$ & $257000-750000[3]$ \\
\hline
\end{tabular}

cost tremendously. Toxicity of crude oil often includes necrosis and congestion of the liver, fat degeneration, and dissociation of hepatocytes. Birds and animals in oil contaminated area usually have black emulsion in the digestive tract with a petroleum odor, which leads to decrease in the absorption of nutrients and eventually to death due to a series of consequences, such as rupture of capillaries and hemorrhage, hepatocellular dissociation, hemosiderosis, renal tubular necrosis, and anemia [7]. Crude oil consists of a number of rather complicated components, which are toxic and can excert side effects on the environment and ecological systems. For instance, the aromatics in crude oil produce particular adverse effects to the local microbial flora. It was found that $\alpha$-pinene, limonene, camphene, and isobornyl acetate were inhibitory to microorganisms. Phenolic and quinonic naphthalene derivatives inhibited the growth of the microbial cells [8]. Increase of naphthalene, 2-methylnaphthalene and pyrene can cause prolonged lag phase and reduce the growth rates of two bacteria [9]. In terms of the toxic effects of cyclohexane on the energy transduction in saccharomyces cerevisiae, cyclohexane inhibited oxygen uptake in intact cells and isolated mitochondria [10]. Therefore, immediate actions should be taken to remove or remediate the contaminant after an accidental spill. Physical cleanup is expensive, and the disruption to the habitats may result in an even worse impact than the oil pollution itself, and such cleanup on the floating water or within plant communities is almost impossible. Chemical approach, such as application of dispersion would cause environmental side effects. For example, coral reef can be affected by crude oil and dis- persants. Early developmental forms (like coral larvae) are particularly sensitive to such toxic effects, and oil slicks can significantly reduce larvae development and viability [11]. Natural oxidation by weathering takes decades due to the lack of oxygen and nutrients in the water for microbial organisms.

Bioremediation through hydrocarbon biodegradation using selected microbial organisms has provided a favorable opportunity because it is environmentally friendly and cost effective. Those microbial species or particular strains can digest hydrocarbons and utilize the resulting compound carbon as food and energy sources for growth and reproduction. Simultaneously the hydrocarbons are hydrolyzed from toxic and complicated organic compounds into nontoxic and simple inorganic compounds, such as $\mathrm{CO}_{2}$ and $\mathrm{H}_{2} \mathrm{O}$ along with microbial biomass accumulation, through oxidation under aerobic conditions. Under certain circumstances, some anaerobic microbial organisms can degrade hydrocarbons as well through reduction. For instance, a benzene-tolerant strain, Flavobacterium sp. DS-711 isolated from deep-sea sediments of $1945 \mathrm{~m}$ had as much as more than $90 \%$ of $n$-alkanes in kerosene degraded [12]. However, oxidation by aerobic microbial organisms has been commonly considered to be a predominant and effective approach to the hydrocarbon degradation. In addition, under anaerobic conditions, some intermediate materials, such as fermentation products, ethanol or methane $\left(\mathrm{CH}_{4}\right)$ can be produced [13]. A large number of related studies, such as specific microbial strain screen and isolation, bench- or lab-scale trials under different environmental conditions, i.e., $\mathrm{pH}$ and temperature, have been conducted with 
promising results. However, the implementation of such technology in a field scale is still very limited. A pilot in situ trial by application of $P$. aeruginosa to degrade hydrocarbons for cleanup of the oil spilled from the Exxon Valdez in Prince William Sound, Alaska [14] seemed unsuccessful due to the low temperature and a lack of essential nutrients for microbial growth and activities.

\section{Isolation and Identification of Microbial Strains to Selectively Degrade Hydrocarbons}

The petroleum crude oil usually consists of $83-87 \%$ carbon and $10-14 \%$ hydrogen, $0.1-2 \%$ nitrogen, 0.1 $1.5 \%$ oxygen, $0.5-6 \%$ sulfur, and $<0.1 \%$ metals [15]. The predominant hydrocarbons are theoretically degradable but the components are rather complicated. It contains aliphatic and polycyclic aromatic hydrocarbons (PAH), for example, crude oil consists of paraffins 15 $60 \%$, naphthenes $30-60 \%$, aromatics $3-30 \%$ and asphaltics $6 \%$ by weight [16]. Therefore, the specific microbial strain screen and isolation need to be performed by supplying petroleum crude oil or a particular component, if the selective strain is going to be utilized to degrade that component, as carbon for food and energy source with mineral nutrients essentially to build up the microbial biomass.

To isolate a microbial hydrocarbon degrader, a common approach is to use an enrichment culture system in which the candidate strain from oil contaminated water or soil samples is cultured in mineral salts medium (MSM) consisting of essential macro- and micro-nutrients

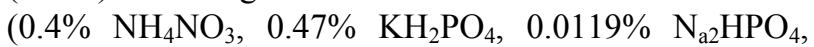
$0.001 \% \quad \mathrm{CaCl}_{2} \cdot 2 \mathrm{H}_{2} \mathrm{O}, \quad 0.1 \% \quad \mathrm{MgSO}_{4} \cdot 7 \mathrm{H}_{2} \mathrm{O}, \quad 0.001 \%$ $\mathrm{MnSO}_{4} \cdot 4 \mathrm{H}_{2} \mathrm{O}$, and $0.0015 \mathrm{FeSO}_{4} \cdot 4 \mathrm{H}_{2} \mathrm{O}$ at pH 7.0 with phosphate buffer) [17]. Basically, microbial organisms are transferred from samples collected to the above MSM medium and cultured at $30^{\circ} \mathrm{C}$ in a rotary shaker at 150 rpm with $0.1 \%$ yeast extract until turbid growth is observed. The bacterial culture is diluted and spread on MSM agar plates containing crude oil (1\%) as carbon source for selective isolation of petroleum degrader. The plates are sealed and incubated at $30^{\circ} \mathrm{C}$ until appearance of several colonies. Individual colonies can be purified by repeating the culture on MSM agar plates containing $1 \%$ crude oil. Identification of the candidate strains will be performed based on physiological and biochemical tests, or $16 \mathrm{~S}$ rRNA sequencing.

Physiological and biochemical tests: using phenotypic and biochemical characterizations to identify specific strains can be performed as described by Yumoto et al. [18].

DNA base composition and DNA-DNA hybridization: The DNA content isolated from bacterial cells can be determined fluorometrically using photo-biotin-labeled DNA probes and microplates [19] and compared with strains in the national collection of microorganisms. For such an approach, Pseudomonas aeruginosa JCM5962 ${ }^{\mathrm{T}}$ and Serratia marcescens JCM $1239^{\mathrm{T}}$ can serve as reference strains.

Phylogenetic analysis using 16S rRNA gene sequence comparison: Almost the full length of 16S rRNA genes of bacteria has been amplified by PCR with following sets of primers 5'-GAGTTTGATCCTGGCTCAG-3' and 5'-AAGGAGGTGATCCAGCC-3' corresponding to the positions 9 to 27 and 1525 to 1541 , respectively [17].

\section{Monitoring and Evaluation of Biodegradation Rate of Hydrocarbons}

To evaluate the biodegradation process of various hydrocarbons, cultured media can be extracted at certain time intervals with dichloromethane. The extract can be analyzed by a gas chromatography (GC), GC-MS (mass spectrometer), gas-liquid chromatography (GLC), or high performance liquid chromatography (HPLC).

With GC analysis, the carrier gas is helium, the injector and detector temperatures are set at $250^{\circ} \mathrm{C}$ and $300^{\circ} \mathrm{C}$, respectively, for analysis of total petroleum hydrocarbons (TPH). However, for gasoline analysis, Wongsa et al. [17] suggested that the column temperature is first maintained at $35^{\circ} \mathrm{C}$ for $5 \mathrm{~min}$, then increased to $220^{\circ} \mathrm{C}$; for diesel oil analysis, the column temperature is set at $50^{\circ} \mathrm{C}$ and then ramped to $270^{\circ} \mathrm{C}$ with a regime of $5^{\circ} \mathrm{C} \cdot \mathrm{min}^{-1}$. In the case of lubricating oil, $320^{\circ} \mathrm{C}$ is needed for both injector and detector temperatures, and the column temperature can be set at $100^{\circ} \mathrm{C}$ initially and ramped to $320^{\circ} \mathrm{C}$ at a rate of $10^{\circ} \mathrm{C} \cdot \mathrm{min}^{-1}$.

For GC-MS analysis, resulting chromatograms can be analyzed by various particular software packages, such as Saturn Software GC/MS Workstation Version 5.52, to identify petroleum components after the spectra have been obtained at temperatures similar to those described in the GC analysis. Detailed information has been provided elsewhere by other researchers [20].

\section{Potential Approaches to Improving Biodegradation of Hydrocarbons and Bioremediation of Oil Pollutants}

\subsection{Performances of Various Bacterial Strains}

Bioremediation approaches, i.e. using selected indigenous microbial organisms to degrade hydrocarbons, are currently receiving favorable publicity because bioremediation is environment friendly and cost effective. Among those microorganisms, the genus Pseudomnas, particularly $P$. putida F1 is one of the most well-studied hydrocarbon degrading bacterial strains, this strain and 
several others are commercially available (ATCC, The Essentials of Life Science Research), having approved the capability to utilize organic compounds from the generic group aliphatic, cyclo-aliphatic, aromatic and/or polynuclear aromatic hydrocarbons. Pseudomnas can facilitate the degradation and utilization of carbon derived from complicated compounds as its food and energy sources with metabolic plasmids. The strains isolated from contaminated sites [14,21,22] have shown promising potential in biodegradation of hydrocarbons and bioremediation of contaminated sites mostly in bench scale studies. For instance, the bioremediation rate of naphthalene using $P$. putida can reach as high as 61 $\mathrm{mg} \mathrm{L}^{-1} \mathrm{hr}^{-1}$ [23]. Strains of P. aeruginosa WatG and Serratia marcescens HokM, isolated in Japan [17], showed that about $90-95 \%$ of diesel oil and kerosene can be degraded within 2 and 3 weeks, and petroleum hydrocarbon (TPH) can be degraded by $72 \%$ in 4 weeks (Figure 1). Moriya and Horikoshi [12] reported that a strain of Flavobacterium sp. named DS-711 isolated from deep sea sediment degraded $90 \%$ of $n$-alkane in kerosene, which is greater than toluene-tolerant $P$. putida. A strain of Bacillus subtilis is a good degrader of both hydrocarbons with degradability of $98 \% n$-hexadecane and $75 \%$ naphthalene [24].

\subsection{Biosurfactant Production}

To effectively degrade hydrocarbons of crude oil, emulsification with a surfactant is of importance due to their low water solubility, especially polyaromatic compo- nents in solid and liquid discharges of petroleum. Some strains, such as $P$. putida, and B. subtilis, can produce rhamnolipid biosurfactant, which can dramatically enhance aqueous dispersion via emulsification, and stimulate the biodegradation of organic compounds $[25,26]$. The emulsification plays an important role in the degradation of organic compounds, especially for polyaromatic hydrocarbons, such as naphthalene and n-paraffin fractions, and such emulsification usually can be observed in 24-48 hrs after inoculation with some effective microbial strains [27]. Other researchers indicated that the dissolution rates for hydrophobic particles into the culture media during the bioremediation process were up to 4 times greater compared to mass transfer rates into abiotic controls due to the production of biosurfactant by P. putida [23].

\subsection{Application of Bacterial Consortium}

Recent research indicates that use of mixed bacterial consortium is more efficient in biodegradation of crude oil than individual bacterial strains. For example, according to Sathish Kumar et al. [28], the mixed consortium of four bacterial strains degraded a maximum of $77 \%$ crude oil, followed by $69 \%$ by Pseudomonas $s p$. BPS1-8, 64\% by Bacillus sp. ISS1-7, $45 \%$ by Pseudomonas sp. HPS2-5, and $41 \%$ by Gorynebacterium sp. BPS2-6 at $1 \%$ crude oil concentration. Increasing crude oil concentration from 1 to $12 \%$, the degradation rate by the same consortium was decreased but still reached up to $45 \%$.

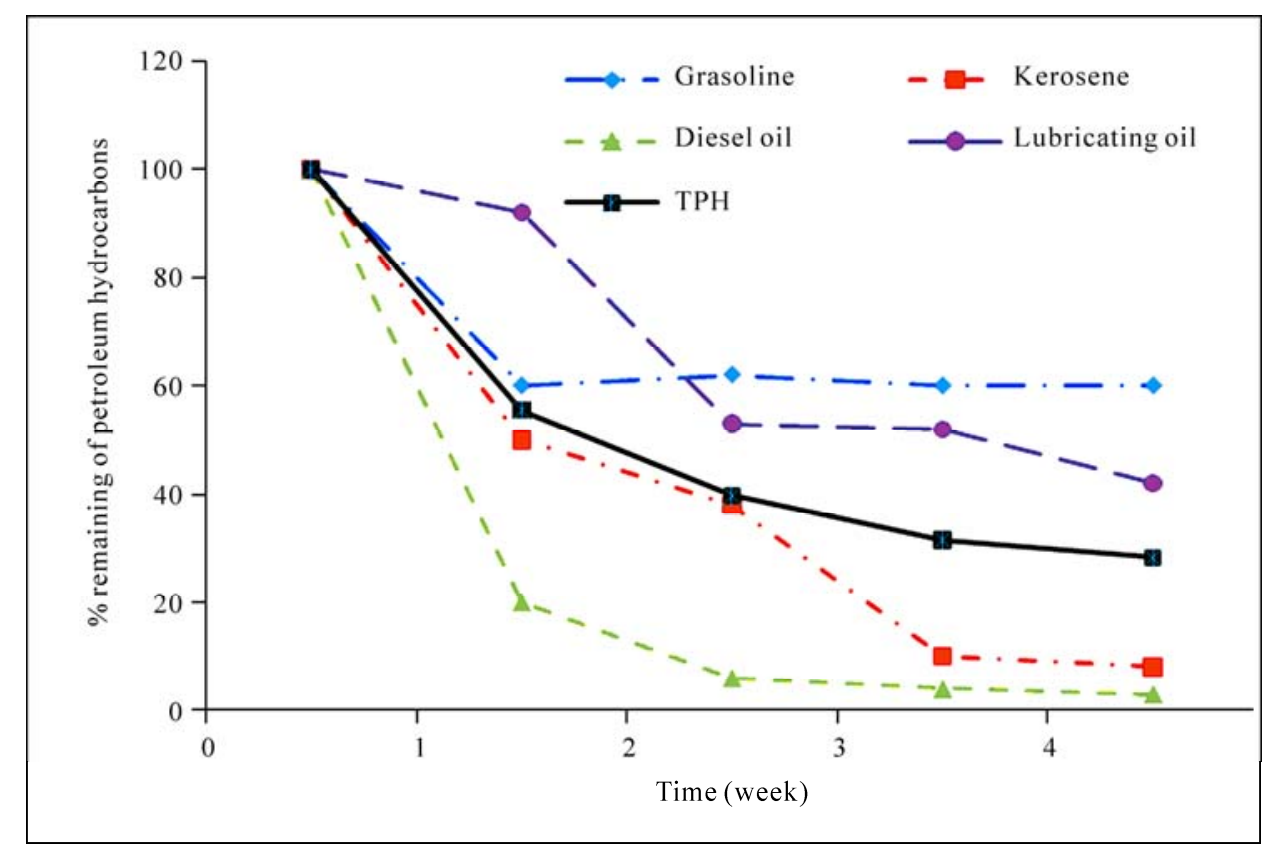

Figure 1. Biodegradation of different hydrocarbon compounds of petroleum products by a selective strain, WatG of Pseudomonas aeruginosa (adapted from Wongsa et al.) [17]. 


\subsection{Biodegradation Time and Efficiency}

Regarding the degradation time, it varies from one researcher to the others. For instance, Atlas and Bartha [29] observed that the degradation started after a 2 to 4 day lag period, and reached its maximum within 2 weeks with their continuous monitoring on $\mathrm{CO}_{2}$ evolution. At this time of degradation, up to $60 \%$ of the crude oil and $75 \%$ of the model hydrocarbon mixture were degraded by Flavobacterium sp. and Brevibacterium sp. isolated from coastal waters after each was added at the final level of $1 \mathrm{ml}$ per $100 \mathrm{ml}$ artificial sea water. Berwick [30] indicated that about $98 \%$ of the solvent (carbon tetrachloride) extractable oil was degraded over 83 days and the degradation in percent was in the following order: aromatics $>$ saturates $>$ heterocyclics $>$ asphalts, but the degradation rate for any of these fractions was above 94\%.

\subsection{Immobilizing Microbial Cells}

Hydrocarbon biodegradation can be significantly improved by immobilizing microbial cells. For example, using the bacterial consortium MPD-M isolated from sediments associated with Colombian mangrove roots can effectively degrade hydrocarbons in water with salinities varying from 0 to $180 \mathrm{~g} / \mathrm{L}$. However, the effectiveness was 4 and 7 times greater with immobilized cells on polypropylene fibers compared to free living cells [31]. Moslemy et al. [32] demonstrated that an enriched bacterial consortium encapsulated in gellan gum microbeads $(16-53 \mu \mathrm{m}$ dia.) at the rate of $2.6 \mathrm{mg} \cdot \mathrm{cells} / \mathrm{g}$ bead degraded over $90 \%$ gasoline hydrocarbons within $5-10$ days for the initial concentration of $50-600 \mathrm{mg} / \mathrm{L}$. However, degrading the same amount of gasoline hydrocarbons by free cells at equivalent levels required as long as 30 days. The improved effectiveness of encapsulation may result from potentially reducing biotic and abiotic stresses, providing a number of advantages, including protecting cells from the toxic effects of hazardous compounds [33-35], and increasing their survival and metabolic activities [36,37].

\subsection{Potential Implementation and in Situ Application}

Successful implementations of crude oil biodegradation in the field scale have been reported. Bacterial strains such as $P$. aeruginosa have been applied to degrade hydrocarbons since 1989 for cleanup of the oil spilled from the Exxon Valdez in Prince William Sound, Alaska [14]. Efficient enzymes extracted from the bacterium Bacillus cereus DQ01 isolated from oil fields have been proven to digest the hydrocarbon, $n$-hexadecane [38]. Alcanivorax borkumensis is a recently discovered hydrocarbonoclastic bacterium. According to Martin dos Santos et al. [39], it might be the most important global oil degrader discovered up to date.

\subsection{Impacts of Environmental Conditions and/or Abiotic Factors on Biodegradation}

The mechanism whereby microorganisms degrade hydrocarbons has not been fully elucidated. It is known that some selective strains possess a capability to tolerate a certain concentration of hydrocarbons and can utilize them as their carbon and energy sources for growth and reproduction. Therefore, the end products of hydrocarbon biodegradation under aerobic conditions are simply $\mathrm{CO}_{2}$, $\mathrm{H}_{2} \mathrm{O}$ and the accumulation of microbial biomass. Since the oxidation or hydrolysis of those hydrocarbons is accomplished by microbes, any factors influencing microbial growth and activities can definitely impact the biodegradation rate and the effectiveness. Moreover certain abiotic conditions such as temperature, $\mathrm{pH}$, oxygen supply and nutrient balance, have been proved to play a crucial role in the oxidation and hydrolysis involved. For instance, temperature of $35^{\circ} \mathrm{C}$ and $\mathrm{pH} 7$ were found to be optimum for maximum degradation of crude oil by a consortium of Pseudomonas strains [28]. Mittal and Singh [40] observed that using degrading consortia of Pseudomonas sp. for bioaugmentation of polycyclic aromatic hydrocarbon (PAH) of polluted soil with addition of nutrients and other environmental factors, i.e., tilling (aeration) resulted in 79\% removal of PAH in 60 days, while only $30 \%$ removal was achieved by indigenous microflora alone. The result was obtained from the nutrient ratio of C:N:P in 120:10:1 based on Gibb's formula (assuming crude oil contains $78 \%$ carbon) but the optimal ratio is unknown. Oxygen and nutrient supply are important to optimize the microbial activity because inhibition of biodegradation by nutrient or oxygen limitation or toxic effects exerted by volatile hydrocarbons may occur due to high concentrations of undispersed hydrocarbons in water [28].

The evidence in improvement of hydrocarbon or crude oil biodegradation by aeration or oxygen supply has been observed by a number of researchers [41-44]. The addition of nutrients adjusts the essential nutrient balance for microbial growth and reproduction, and oxygen supply can maintain the aerobic environmental condition to stimulate the microbial oxidation and hydrolysis of hydrocarbon compounds. As matter of fact, in soil or water with high levels of hydrocarbon contamination, the oxygen demand often exceeds the supply, which is the reason that the amount of oxygen supply was the most important single factor affecting biodegradation of petroleum [45]. 


\subsection{Oxygen Supply and Nutrient Balancing to Improve Hydrocarbon Biodegradation for Bioremediation of Oil Pollutants}

Both biotic and abiotic conditions play a crucial role in improvement of the bioremediation efficiency due to optimization of function of indigenous microbial strains. With application of efficient strains isolated, abiotic condition improvement can definitely increase the biodegradation efficiency and effectiveness. Among which, temperature and $\mathrm{pH}$ are adjustable factors in a bench scale trial but unrealistic to be implemented with an in situ approach. Nutrient balancing, especially the supply of essential nutrients such as $\mathrm{N}$ and $\mathrm{P}$ can improve the biodegradation efficiency by optimizing the bacterial $\mathrm{C}: \mathrm{N}: \mathrm{P}$ ratio. However, appropriate rate and application method are of great importance as insufficient rate cannot balance the nutrient ratio but excess amount will produce toxic effects to microbial organisms. In addition, the impact of nutrient supply on water quality may bring public concerns on a possible eutrophication risk. The limited quantity of supply is required only to provide an appropriate rate to microbial organisms for their growth and reproduction. Therefore, it is urgently needed to study the bacterial consumption rate and the optimum ratio of such nutrients required by efficient microbial strains. Nutrient fate and consequences of biodegradation of hydrocarbons associated with nutrient supply to influence the environment and water quality should be monitored. Also, to prevent toxic effects on microbial organisms by abrupt supply of these nutrients, slow release controlled by polymers can be an ideal approach as it provides prolong and constant supply of nutrients to microbes. Oxygen supply has been evidently proved to be a stimulating approach to assist microbial degradation of hydrocarbons [46] because oxidation and hydrolysis are primary procedures to break down the complicated hydrocarbon compounds to be utilized by microbial organisms for food.

Regarding oxygen source, it requires a slow but a consistent supply to create an aerobic environment for the microbial strains. The introduction of solid peroxygen materials provides a viable alternative for meeting the oxygen demand by microbial organisms [46]. These materials are primarily peroxide salts of calcium and magnesium: $\mathrm{CaO}_{2}$ and $\mathrm{MgO}_{2}$, which can release oxygen at enhanced levels over extended time periods as described below:

$$
\begin{gathered}
\mathrm{CaO}_{2}+2 \mathrm{H}_{2} \mathrm{O} \rightarrow \mathrm{Ca}(\mathrm{OH})_{2}+\mathrm{H}_{2} \mathrm{O}_{2} \\
2 \mathrm{H}_{2} \mathrm{O}_{2} \rightarrow \mathrm{O}_{2}+2 \mathrm{H}_{2} \mathrm{O} \\
\mathrm{MgO}_{2}+\mathrm{H}_{2} \mathrm{O} \rightarrow 1 / 2 \mathrm{O}_{2}+\mathrm{Mg}(\mathrm{OH})_{2}
\end{gathered}
$$

Indeed, calcium or magnesium peroxide is a powerful oxidizing agent and it breaks down into lime, water and oxygen, which does not form any persistent, toxic residual compounds. The other ideal oxide material is calcium superoxide, $\mathrm{CaO}_{4}$ or $\mathrm{Ca}\left(\mathrm{O}_{2}\right)_{2}$, which contains higher percentage of stored oxygen than $\mathrm{CaO}_{2}$, which has been used in emergency breathing apparatus for miners and as auxiliary oxygen sources for astronauts. Both of them have similar physical and chemical characteristics but the former can release a double amount of $\mathrm{O}_{2}$ with water compared to the latter with the following reaction [47, 48]:

$$
\begin{aligned}
\mathrm{CaO}_{4}+\mathrm{xH}_{2} \mathrm{O} \rightarrow \underset{\mathrm{CaO}_{2}}{\downarrow} \times \mathrm{xH}_{2} \mathrm{O}+\mathrm{O}_{2} & \\
& \\
\mathrm{Ca}(\mathrm{OH})_{2}+ & \mathrm{xH}_{2} \mathrm{O}_{2} \\
& \downarrow \\
& \mathrm{O}_{2}+\mathrm{xH}_{2} \mathrm{O}
\end{aligned}
$$

From which, double amount of oxygen can be released from $\mathrm{CaO}_{4}$ as compared to $\mathrm{CaO}_{2}$ to meet the microbial requirement for oxygen but there is no toxic substance produced. In addition, to avoid possible toxic effects by $\mathrm{CaO}_{4}$, polymers can be applied to separate each component to prevent direct contacts of microbial organisms with calcium superoxide. The production of $\mathrm{CaO}_{4}$ can be accomplished by the reaction of potassium superoxide $\left(\mathrm{KO}_{2}\right)$, which is commercially available, with calcium chloride $\left(\mathrm{CaCl}_{2}\right)$ in accordance with the following equation [49]:

$$
2 \mathrm{KO}_{2}+\mathrm{CaCl}_{2} \rightarrow \mathrm{CaO}_{4}+2 \mathrm{KCl}
$$

Therefore, to improve the hydrocarbon degradation efficiency and effectiveness, it is important to utilize indigenous microbial strains isolated specifically for crude oil degradation that are commercially available, or identified and isolated from enrichment culture and screening. Apply solid oxygen materials, such as calcium superoxide, and adjust nutrient balance, especially to optimize $\mathrm{C}: \mathrm{N}: \mathrm{P}$ ratio for efficient degradation of hydrocarbons of crude oil under optimum environmental conditions, such as appropriate temperature and $\mathrm{pH}$ values in the media.

Regarding the nutrient supply, the controlled release substrate with optimal ratio can provide the microbial organisms a slow and constant nutrient supply under the controlled conditions. Previous studies have displayed that the addition of essential metabolic nutrients, $\mathrm{N}$ and $\mathrm{P}$, to oil contaminated beaches is an effective approach for stimulating bioremediation of oil pollutants by indigenous microbial biomass [50-52]. However, the application of excessive amount of nutrients over metabolic needs by microbes can result in extra bioremediation costs and potential marine eutrophication impacts [53]. The use of slow release nutrients with an appropriate rate may provide a continuous nutrient supply by maintaining a sufficient nutrient status for the perpetuation of microbial metabolic activities without causing environmental 
concerns and save the cost [54]. Xu et al. [55] found out that an addition of $0.8 \%$ of slow-release fertilizer, Osmocote $^{\mathrm{TM}}$ consisting of $18,4.8$, and $8.3 \% \mathrm{~N}-\mathrm{P}-\mathrm{K}(\mathrm{w} / \mathrm{w})$ to oil polluted sediments was sufficient to maximize metabolic activity of the microbial biomass and the biodegradation of straight-chain alkanes $\left(\mathrm{C}_{10}-\mathrm{C}_{33}\right)$; and application of $1.5 \%$ rate resulted in optimal biodegradation of recalcitrant branched-chain alkanes, such as pristine and phytane. The application of soluble nutrients to the oil contaminated sites has shown an especially promising potential of the indigenous microbial organisms for stimulating biodegradation of petroleum hydrocarbons in the tropical environment of Singapore with high temperature and humidity [56]. Therefore, to improve the biodegradation efficiency and implementation, integrating various components, such as microbial strains in consortium, solid oxygen source, appropriate rate of nutrients with controlled release pattern, into a granule formulation with an oleophilic matrix, may provide an ideal approach to improving bioremediation of crude oil pollutants.

\section{REFERENCES}

[1] S. Harvey, "California's legendary oil spill," Los Angeles Times, 13 June 2010. http://articles.latimes.com/2010/jun/13/local/la-me-then-2 0100613

[2] Anonymous, “Oil spill,”2010. http://en.wikipedia.org/wiki/oil_spill

[3] E. Bluemink, "Size of Exxon Spill Remains Disputed," Anchorage Daily News, 2010. http://www.adn.com/2010/06/05/1309722/size-of/esxon-s pll-remains-disputed.html

[4] B. Marsh, "Even with a Cleanup, Spilled Oil Stays with Us," The New York Times, 6 June 2010.

[5] I. Mundi, "World Crude Oil Consumption by Year", 2010. http://www.indexmundi.com/energy. aspx

[6] J. T. Tevvors and M. H. Jr. Saier, "The Legacy of Oil Spills," Water, Air and Soil Pollution, Vol. 211, No. 1, 2010, pp. 1-3. doi:10.1007/s11270-010-0527-5

[7] R. A. Khan and P. Ryan, "Long Term Effects of Crude Oil on Common Murres (Uria Eagle) Following Rehabilitation," Bulletin of Environmental Contamination and Toxicology, Vol. 46, No. 2, 1991, pp. 216-222. doi:10.1007/BF01691940

[8] J. Sikkema, A. M. deBont and B. Poolman, "Mechanisms of Membrane Toxicity of Hydrocarbons," Microbial Review, Vol. 59, 1995, pp. 201-222.

[9] J. A. Calder and J. H. Lader, "Effect of Dissolved Aromatic Hydrocarbons on the Growth of Marine Bacteria in Batch Culture," Applied Environmental Microbiology, Vol. 32, No. 1, 1976, pp. 95-101.

[10] S. Uribe, P. Rangel, G. Espinotal and G. Aguirre, "Effects of Cyclohexane, an Industrial Solvent, on the Yeast Sac- charomyces Cerevisiae and on Isolated Yeast Mitochondria," Applied Environmental Microbiology, Vol. 56, 1990, pp. 2114-2119.

[11] C. Hansen, "Coral Reefs and Oil Spills: What You Might not Know," The Sticky Tongue, Herpetology, Zoology and Conservation, 2010.

http://thestickytongue.com/2010/08/02/coral-reefs-and-oil -spills-what-you-might-not-know.

[12] K. Moriya and K. Horikoshi, "Isolation of Benzene-Tolerant Bacterium and Its Hydrocarbon Degradation," Journal of Fermentation and Bioengineering, Vol. 76, 1993, No. 3, pp. 168-173.

[13] E. A. Paul and F.E. Clark, "Soil Microbiology and Biochemistry," $2^{\text {nd }}$ Ed., Academic Press, San Diego, 1996.

[14] S. Harvey, I. Elashvilli, J. J. Valdes, D. Kamely and A. M. Chakrabarty, "Enhanced Removal of Exxon Valdez Spilled Oil from Alaskan Gravel by a Microbial Surfactant," Nature Biotechnology, Vol. 8, No. 3, 1990, pp. 228-230. doi:10.1038/nbt0390-228

[15] J. G. Speight, "The Chemistry and Technology of Petroleum," Marcel Dekker, New York, 1999.

[16] N. J. Hyne, "Nontechnical Guide to Petroleum Geology, Exploration, Drilling, and Production," PennWell Corporation, Tulsa, 2001.

[17] P. Wongsa, M. Tanaka, A. Ueno, M. Hasanuzzaman, I. Yumoto and H. Okuyama, "Isolation and Characterization of Novel Strains of Pseudomonas Aeruginosa and Serratia Marcescens Possessing High Efficiency to Degrade Gasoline, Kerosene, Diesel Oil and Lubricating Oil," Current Microbiology, Vol. 49, 2004, pp. 415-422. doi:10.1007/s00284-004-4347-y

[18] I. Yumoto, T. Kusano, T. Shingyo, Y. Nodasaka, H. Matsuyama and H. Okuyama, "Assignment of Pseudomonas sp. Strain E-3 to Pseudomonas Psychrophila Sp. Nov., a New Facultatively Psychrophilic Bacterium," Estremophiles, Vol. 5, No. 5, 2001, pp. 343-349.

[19] T. Ezaki, Y. Hashimoto and E. Yabuuchi, "Fluorometric Deoxyribonucleic Acid-Deoxyribonucleic Acid Hybridization in Microdilution Wells as an Alternative to Membrane Filter Hybridization in Which Radioisotopes are Used to Determine Genetic Relatedness among Bacterial Strains," International Journal in Systematic Bacteriology, Vol. 39, No. 3, 1989, pp. 224-229. doi:10.1099/00207713-39-3-224

[20] S. H. Tzing, J. Y. Chang, A. Ghule, J. J. Chang, B. Lo and Y. C. Ling, "A Simple and Rapid Method for Identifying the Source of Spilled Oil Using an Electronic Nose: Confirmation by Gas Chromatography with Mass Spectrometry," Rapid Communication in Mass Spectrometry, Vol.17, No. 16, 2003, pp. 1873-1880. doi: $10.1002 / \mathrm{rcm} .1127$

[21] J. Olsen, "Pseudomonas Degradation of Hydrocarbons," United States Patent \# 4508824, United States Patent Office, 1985 .

[22] R. G. Binder, K. Numata, D. A. Lowe, T. Murakami and J. L. Brown, "Isolation and Characterization of a Pseudomonas Strain Producing Glutaryl-7-Aminocephalospo- 
ranic Acid Acylase," Applied and Environmental Microbiology, Vol. 59, No. 10, 1993, pp. 3321-3326.

[23] R. Yu, M. Nemati, G. Hill and J. Haddley, "Mass Transfer and Bioremediation of Naphthalene and Methyl Naphthalenes in Baffled and Bead Mill Bioreactors," The Canadian Journal of Chemical Engineering, Vol. 84, No. 3, 2006, pp. 349-355. doi:10.1002/cjce.5450840311

[24] N. Christova, B. Tuleva and B. Nikolova-Damyanova, "Enhanced Hydrocarbon Biodegradation by a Newly Isoloated Bacillus Subtilis Strain," Zeitschrift für Naturforschung, Vol. 59c, 2003, pp. 205-208.

[25] A. Oberbremer, R. Muller-Hurtig and F. Wagner, "Effect of the Addition of Microbial Surfactants on Hydrocarbon Degradation in a Soil Population in a Stirred Reactor," Applied Microbiology and Biotechnology, Vol. 32, No. 4, 1990, pp. 485-489. doi:10.1007/BF00903788

[26] Y. Zhang and R. M. Miller, "Enhanced Octadecane Dispersion and Biodegradation by a Pseudomonas Rhamnolipid Surfactant (Biosurfactant)," Applied Environmental Microbiology, Vol. 58, No. 10, 1992, pp. 32763282.

[27] J. E. Zajic and B. Supplisson, "Emulsificaiton and Degradation of 'Bunker C' Fuel Oil by Microorganisms," Biotechlogy and Bioengineering, Vol. 14, 1972, pp. 331343. doi:10.1002/bit.260140306

[28] M. Sathishkumar, A. R. Binupriya, S. H. Baik and S. E. Yun, "Biodegradation of Crude Oil by Individual Bacterial Strains and a Mixed Bacterial Consortium Isolated from Hydrocarbon Contaminated Areas," Clean, Vol. 36, No. 1, 2008, pp. 92-96. doi:10.1002/bit.260140303

[29] R. M. Atlas and R. Bartha, "Degradation and Mineralization of Petroleum by Two Bacteria Isolated from Coastal Waters," Biotechnology and Bioengineering, Vol. 14, No. 3, 1971, pp. 297-308.

[30] P. G. Berwick, "Physical and Chemical Conditions for Microbial Oil Degradation," Biotechnology And Bioengineering, Vol. 26, No. 11, 1984, pp. 1294-1305. doi:10.1002/bit.260261106

[31] M. P. Diaz, K. G. Boyd, S. J. W. Grigson and J. G. Burgess, "Biodegradation of Crude Oil Across a Wide Range of Salinities by an Extremely Halotolerant Bacterial Consortium Mpd-M, Immobilized onto Polypropylene Fibers," Biotechnology and Bioengineering, Vol. 79, 2002, pp. 145-153. doi:10.1002/bit.10318

[32] P. Moslemy, R. J. Neufeld and S. R. Guiot, "Biodegradation of Gasoline by Gellan Gum-Encapsulated Bacterial Cells," Biotechnology and Bioengineering, Vol. 80, No. 2, 2002, pp. 175-184. doi:10.1002/bit.10358

[33] H. Bettmann and H. J. Rehm, "Degradation of Phenol by Polymer Entrapped Microorganisms," Applied Microbiology and Biotechnology, Vol. 20, No. 5, 1984, pp. 285290. doi:10.1007/BF00270587

[34] S. Manohar and T. B. Karegoudar, "Degradation of Naphthalene by Cells of Pseudomonas Sp. Strain Ngk 1 Immobilized in Alginate, Agar and Polyacrylamid," Applied Microbiology and Biotechnology, Vol. 49, No. 6, 1998, pp. 785-792. doi:10.1007/s002530051247
[35] M. L. Paje, P. Marks and I. Couperwhite, "Degradation of Benzene by a Rhodococcus Sp. Using Immobilized Cell Systems," World Journal of Microbiology and Biotechnology, Vol. 14, 1998, pp. 675-680. doi:10.1023/A:1008898922908

[36] B. M. Hall, A. J. CcLoughlin, K. T. Leung, J. T. Trevors and H. Lee, "Transport and Survival of Alginate-Encapsu-Lated and Free Lux-Lac Marked Pseudononas Areruginousa UG2Lr Cells in Soil," FEMS Microbiology and Ecology, Vol. 26, 1998, pp. 51-61. doi:10.1111/j.1574-6941.1998.tb01561.x

[37] T. Suzuki, T. Yamaguchi and M. Ishida, "Immobilization of Prototheca Zopfi in Calcium-Alginate Beads for the Degradation of Hydrocarbons," Process of Biochemistry, Vol. 33, 1998, pp. 541-546. doi:10.1016/S0032-9592(98)00022-3

[38] H. Wang and Y. Chen, "The Microbial Hydrocarbon Diet," Science and Technology News, 2005. http://www.physorg.com/news163937198.html

[39] V. A. P. Martins dos Santos, M. M. Yakimov, K. N. Timmis and P. N. Golyshin, "Genomic Insights into Oil Biodegradation in Marine Systems: Chapter 9," E. Diaz Ed., Microbial Biodegradation: Genomics and Molecular Biology, Caister Academic Press, U.K., 2008.

[40] A. Mittal and P. Singh, "Polycyclic Aromatic Hydrocarbon Degradation by Developed Consortium in Microcosms Study," The Internet Journal of Microbiology, Vol. 7, No. 1, 2009, pp. 1-12.

[41] G. Soli and E. M. Bens, "Bacteria Which Attack Petroleum Hydrocarbons in a Saline Medium," Biotechnology and Bioengineering, Vol. 14, No. 3, 1971, pp. 319-330. doi:10.1002/bit.260140305

[42] R. Atlas, "Microbial Hydrocarbon Degradation-BioremeDiation of Oil Spills," Journal of Chemical Technology \& Biotechnology, Vol. 52, No. 2, 1991, pp. 149-156. doi:10.1002/jctb.280520202

[43] D. Miethe, V. Riis and W. Babel, "The Relationship between the Microbial Activity of the Autochthonos Microorganisms of Pristine and Contaminated Soils and Their Potential for The Degradation of Mineral Oil Hydrocarbons," Acta Biotechnologica, Vol. 14, No. 2, 1993, pp. 131-140. doi:10.1002/abio.370140204

[44] S. R. Peressutti, H. M. Alvarez and O. H. Pucci, "Dynamics of Hydrocarbon-Degrading Bacteriocenosis of an Experiment on Oil Pollution in Patagonian Soil," International Biodeterioration and Biodegradation, Vol. 52, No. 1, 2003, pp. 21-30. doi:10.1016/S0964-8305(02)00102-6

[45] J. S. Devinny and R. L. Islander, "Oxygen Limitation in Land Treatment of Concentrated Wastes," Hazardous Waste And Hazardous Material, Vol. 6, No. 4, 1989, pp. 421-433. doi:10.1089/hwm.1989.6.421

[46] J. W. Davis, R. J. West and G. M. Kecka, "Enhanced Land Treatment of Petroleum-Contaminated Soils Using Solid Peroxygen Materials," Remediation Journal, Vol. 7, No. 2, 1997, pp. 67-81. doi:10.1002/rem.3440070205

[47] R. S. Johnston, E. D. Osgood and R. R. Miller, "Analysis of Mixed Oxides of Calcium," Analytical Chemistry, Vol. 
30, No. 4, 1958, pp. 511-513. doi: $10.1021 / \mathrm{ac} 60136 \mathrm{a} 018$

[48] E. V. Ballou, P. C. Wood and L. Spitze, "The Preparation of Calcium Superoxide from Calcium Peroxide Diperoxyhydrate," Industrial and Engineering Chemistry Product Research and Development, Vol. 16, No. 2, 1993, pp. 180-186. doi:10.1021/i360062a015

[49] J. S. Hashman, E. City, J. C. Renforth and V. J. W. Berkstresser, "Production of Calcium Superoxide," United States Patent \#3119665, United States Patent Office, 1964.

[50] R. M. Atlas and R. Bartha, "Hydrocarbon Biodegradation and Oil Spill Bioremediation," Advances in Microbial Ecology, Vol. 12, 1992, 287-338.

[51] A. D. Venosa, "Oil Spill Bioremediation on Coastal Shorelines: a Critique," S. K. Sikdar and R. L. Irvine, Eds., Bioremediation: Principles and Practice, Lancaster, PA, 1998, pp. 280-296.

[52] C. R. Johnson and K.M. Scow, "Effect of Nitrogen and Phosphorus Addition on Phenanthrene Biodegradation in
Four Soils," Biodegradation, Vol. 10, No. 1, 1999, pp. 43-50. doi:10.1023/A:1008359606545

[53] J. T. Dibble and R. Bartha, "Effect of Environmental Parametes on the Biodegradation of Oil Sludge," Applied and Environmental Microbiology, Vol. 37, No. 4, 1979, pp. 729-739.

[54] E. Riser-Roberts, "Bioremediation of Petroleum Contaminated Sites," Chelsea, MI, 1992, pp. A173-179.

[55] R. Xu, J. P. Obbard and E. T. C. Tay, "Optimization of Slow-Release Fertilizer Dosage for Bioremediation of Oil-Contaminated Beach Sediment in a Tropical Environment," World Journal of Microbiology and Biochemistry, Vol. 19, 2003, pp. 719-725. doi:10.1023/A:1025116421986

[56] M. Mathew, J. P. Obbard, T. P. Ting, Y. H. Gin and H. M. Tan, "Bioremediation of Oil Contaminated Beach Sediments Using Indigenous Microorganisms in Singapore," Acta Biotechnologica, Vol. 19, No. 3, 1999, pp. 225-233. doi:10.1002/abio.370190309 